\title{
Eco-oriented management accounting system as a tool for sustainable functioning of an economic entity
}

\author{
Natalia Varaksa*, Maria Alimova, and Sergey Alimov \\ Orel State University named after I.S. Turgenev, Naugorskoe highway, 40, 302020 Orel, Russia
}

\begin{abstract}
Modern challenges of a global nature, as well as dependence on environmental impacts, dictate the need to determine environmental costs for economic entities, as well as account, analyze and control them. In this regard, the system of environmental management accounting is one of the tools that ensure the sustainable functioning of the enterprise. The article examines the categorical apparatus of an eco-oriented management accounting system in order to study the presented topic. The paper propose a system of information support for environmental management accounting for the purpose of improving environmental safety and leveling existing environmental risks. The main objects of environmental management accounting are identified and the reflection of payments in the environmental sphere on a separate account with the necessary level of detail for the effective functioning of the system is justified. The paper also formulates problems for further research of the environmental management accounting system using advanced achievements and practices in the world scientific arena.
\end{abstract}

\section{Introduction}

The course on the greening of the economy and sustainable economic development determines the need for the introduction of an environmental management system for economic entities under ISO 14007:2019 [1]. The world experience in the implementation of an integrated environmental management system indicates the existence of important benefits for a company in the form of market and competitive advantages, reduction of organizational risks, etc. The assessment of environmental costs determines the need for the formation of an environmental management accounting system.

The need for the formation, subsequent generalization, and systematization of information flows within the functioning of an environmentally oriented management accounting system, as well as the search for adequate tools of this system that meet modern realities and external challenges are largely determined by increasing environmental risks both at the enterprise level and at the state level.

The process of forming a system of environmental management accounting in Russia is currently at the preparatory stage, which explains the underdevelopment and lack of

\footnotetext{
*Corresponding author: natalia.varaksa@yandex.ru
} 
elaboration of methodological tools in this area. Existing studies on the construction of an environmental accounting system at enterprises in various sectors of the national economy and the use of methods for generating information about the amount of environmental costs do not disclose all the advantages and specific features of environmental management accounting.

In these conditions, the currently undeveloped system of environmental management accounting in Russia requires detailed and in-depth research from the standpoint of its formation and functioning.

\section{Materials and Methods}

The methodological tools of the study include general scientific methods, in particular, methods of analysis, comparison, and correlation were used to obtain results and formulate conclusions in the field of development of the environmental management accounting system. Information pots of the eco-oriented system were studied on the basis of graphical interpretation tools. The categorical apparatus was studied using such methods of scientific research as literary analysis, hypothesis building, and expert assessment. The provisions of the study are also reasoned with the help of a systematic approach and private scientific methods.

Considering the theoretical basis of the study, we note that many foreign scientists raise issues of environmental management and the concept of environmental management accounting, assess the effectiveness of these tools in reducing environmental impact, correlate them with the directions of sustainable development of the company.

The need to implement an eco-oriented management accounting system at industrial enterprises was justified by Mohamed Marouen Amiri1, Hédi Noubbigh1, Kamel Naoui1 \& Nouha Choura based on the analysis of the relationship between the performance indicators of French organizations, including productivity, and the process of implementing the principles of environmental accounting [2].

Scientists of the Polytechnic University of Turin - Claudio Comoglio, Serena Botta studied the impact of the implementation of the management accounting system for environmental costs at industrial enterprises in Italy on the overall performance indicators of their operating activities, as well as the comprehensive improvement of environmental indicators of their work. These developments resulted in the conclusion that environmental efficiency is not synonymous with economic efficiency, however, the optimization of environmental payments is a significant tool for ensuring sustainable environmental and economic development of the company by introducing the principles of environmental management accounting into its activities [3].

From a practical point of view, the study by Delphine Gibassier, Simon Alcouffe, which reveals the management of environmental and economic performance through the development and implementation of an appropriate environmentally friendly accounting system, as well as methods and principles of accounting for environmental costs, is of interest. At the same time, the tasks of this accounting system include not only the accounting of environmental payments but also the aggregated accounting of environmental costs, the assessment of benefits, and strategic planning within the interaction of an economic entity with the environment [4].

The relationship of environmental management accounting with the sustainability of the company was investigated by S. Schaltegger, highlighting planetary boundaries in the context of corporate accounting [5]. L. Johnstone recognized the importance of social control in environmental management and environmental corporate accounting [6]. 
Eka Siskawati, Eko Ganis Sukoharsono, Rosidi, Abdul Ghofar, Daniel T.H. Manurung studied the role of environmental management accounting in reporting on the company's environmental performance using the example of Tango Company [7].

In Russia, there is a small number of scientific works devoted to this issue, representing the management system of environmental costs from a generalized research position. Silina, A.V., Batishcheva N.N. explores the system of environmental management accounting as a subsystem of management accounting formed by environmental-oriented management of production processes, personnel, financial flows, and other elements within the environmental activities of the enterprise [8]. Maslennikova I.S. identifies the elements of environmental management accounting: the organizational structure, the process of planning and implementing specific provisions of environmental policy, the distribution and measures of responsibility for the implementation of these provisions, the necessary accounting procedures, as well as processes that allow timely assessment of the results achieved and develop directions for improving the environmental policy of the enterprise [9]. According to Chkhutiashvili L.V., environmental management accounting is the process of reflecting in the accounting the costs and obligations of economic entities for environmental protection activities, as well as the socio-ecological and economic results of the organization's activities in order to improve the efficiency of business management, as well as to achieve an optimal economic and environmentally safe position in the market [10].

Thus, there are no systematic studies on environmental management accounting in Russia, and the regulatory and legal regulation of the basics of building and functioning of the accounting system in this area as a whole is not sufficiently developed.

\section{Discussion and Results}

To date, separate regulatory legal acts in Russia establish various types of environmental payments, and also separately determine the procedure for the formation of environmental reporting. The information base for making management decisions in the environmental sphere is the data generated in the accounting system, namely, on the accounts of synthetic and analytical accounting [11].

In our opinion, environmental-oriented management accounting is a system of interrelated and interacting elements of accounting for environmental costs, environmental obligations, environmental reporting, and environmental audit. From the point of view of increasing the reliability and efficiency of the information generated in the environmental management accounting system, it is necessary to improve the process of reflecting environmental payments in the accounting. Data on the amount of payments made in the environmental sphere should be reflected on a separate account allocated for these purposes with the necessary level of detail. It is proposed to charge charges for negative impact on the environment on account 22 "Environmental Costs" with the opening of the following subaccounts:

- subaccount 1 "Payment for the Negative Impact in the Form of Emissions of Pollutants Into the Atmospheric Air by Stationary Sources Within the Established Standards";

- subaccount 2 "Payment for Negative Impact in the Form of Discharges of Pollutants Into Water Bodies Within the Established Standards";

- sub-account 3 "Payment for Negative Impact in the Form of Storage, Disposal of Production and Consumption Waste Within the Established Standards";

- subaccount 4 "Environmental Fees";

- subaccount 5 "Payment for the Negative Impact in the Form of Emissions of Pollutants Into the Atmospheric Air by Stationary Sources Above the Established Standards"; 
- subaccount 6 "Payment for Negative Impact in the Form of Discharges of Pollutants Into Water Bodies Above the Established Standards";

- sub-account 7 "Payment for Negative Impact in the Form of Storage, Disposal of Production and Consumption Waste Above the Established Standards";

- subaccount 8 "Sanctions for Violation of the Procedure for Payment of Environmental Payments".

For trade enterprises, account 22 should be replaced by account 47 with a similar order of detail.

This event will significantly increase the information content of the accounting system in relation to environmental payments, and also focuses the attention of owners in relation to excess payments for negative environmental impact. This, in turn, will serve as an incentive for the implementation of environmental protection measures, the modernization of technological processes and equipment in the framework of minimizing the negative impact on the environment by enterprises of various sectors of the economy.

Figure 1 presents the management accounting of environmental payments within the proposed modernization of the accounting process.

Enterprises that incur significant environmental costs and pay a variety of environmental fees are required to generate environmental management reporting for the following facilities:

- environmental payments;

- costs associated with the production of eco-friendly products;

- costs of disposal of various types of waste;

- the cost of eliminating the consequences of negative environmental impacts;

- costs of compulsory and voluntary environmental insurance;

- costs for environmental education and training;

- the cost of research and development work;

- results from the implementation of environmental protection measures.

At the same time, the process of drawing up environmental management reporting should be combined with the formation of annual accounting (financial) statements. It should contain information about the environmental and economic goals of the enterprise to ensure its sustainable economic growth. 


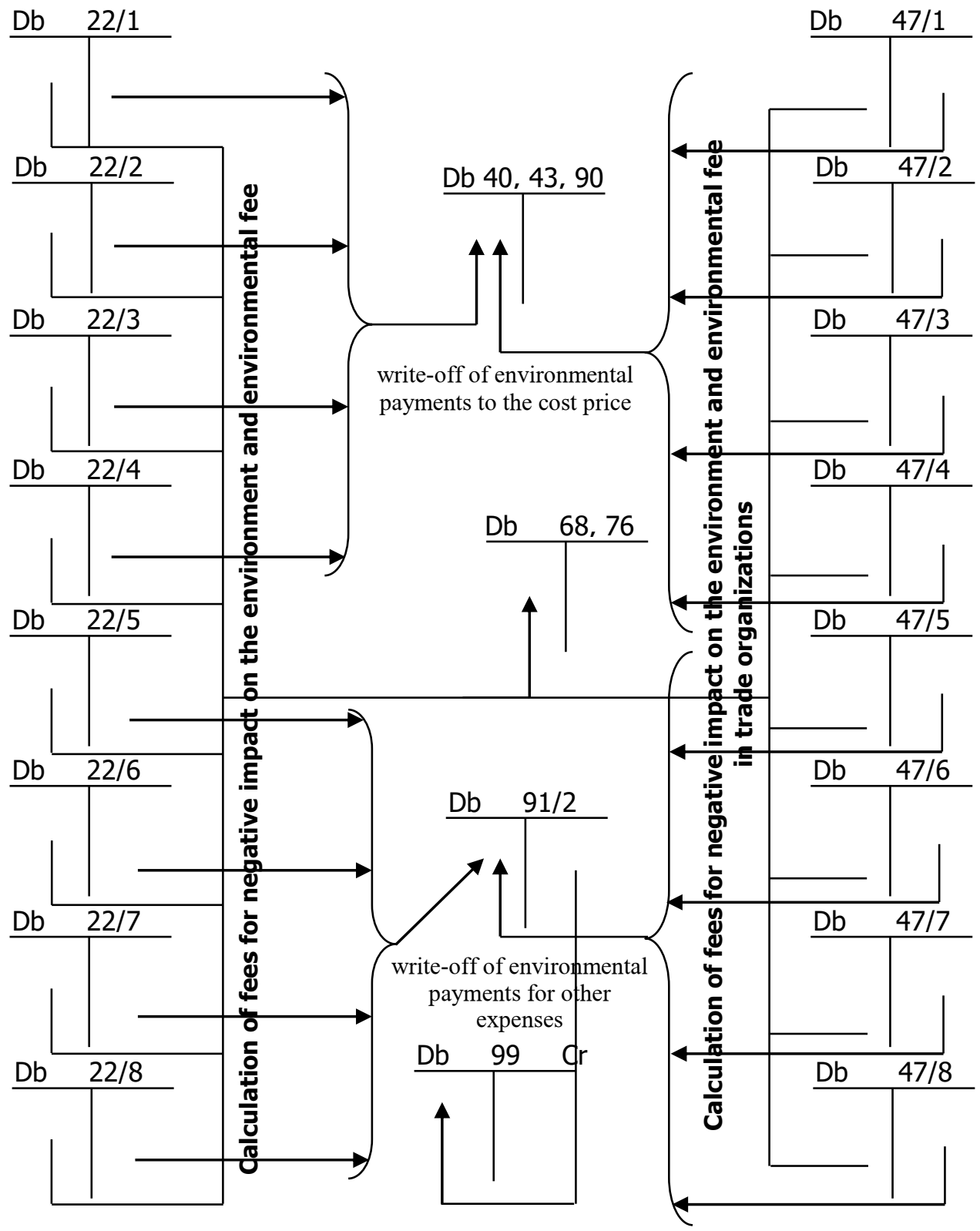

Fig. 1. Information support for management accounting of environmental payments as part of the proposed modernization of the accounting process

\section{Conclusions}

The article discusses the author's vision of such an important category from the point of view of ensuring environmental safety as the "eco-oriented management accounting system". The article has been studied processes of formation of an information base on environmental payments in the accounting system of an enterprise and a set of reporting 
documents in relation to environmental measures and environmental costs carried out by an economic entity. It also proposes information support for management accounting of environmental payments as part of the proposed modernization of the accounting process with the allocation of a separate account for reflecting environmental payments.

The functioning of the system of environmental management accounting at enterprises of various sectors of the national economy will minimize the likelihood of environmental disasters, as well as the negative impact of industrial enterprises on the environment since it will not only help to inform various business entities about the extent of the impact on the environment and measures to eliminate the consequences, but also create prerequisites for the development of environmental culture. It will enable administrative bodies to carry out regulatory management of environmental processes in the regions and the state as a whole.

\section{References}

1. Environmental management. Guidelines for determining environmental costs and benefits (2020), http://protect.gost.ru/

2. Mohamed Marouen Amiri1, Hédi Noubbigh1, Kamel Naoui1, Nouha Choura, International Journal of Business and Management, 10(11), 107 (2015)

3. C. Comoglio, S. Botta, The Journal of Cleaner Production, 2, 92 (2012)

4. Delphine Gibassier, Simon Alcouffe, Social and Environmental Accountability Journal, 38(1) (2018)

5. S. Schaltegger, Social and Environmental Accountability Journal, 38(1) (2018)

6. L. Johnstone, Social and Environmental Accountability Journal, 38(1) (2018)

7. Eka Siskawati, Eko Ganis Sukoharsono, Rosidi, Abdul Ghofar, Daniel T.H. Manurung, Journal of Environmental Accounting and Management, 7(3), 253 (2019)

8. A.V. Silina, N.N. Batishcheva, Economics and Management, 4-1 (6), 37 (2016)

9. I.S. Maslennikova, L.M. Kuznetsov, Environmental management and audit, 328 (2016)

10. L.V. Chkhutiashvili, Moscow Region Accountant Bulletin, 3 (2012)

11. L.V. Popova, S.A. Alimov, M.S. Alimova, Bulletin of professional accountants, 5, 19 (2016) 